\title{
The Development of Municipal General Hospitals in English County Boroughs in the 1930s
}

\author{
ALYSA LEVENE, MARTIN POWELL and JOHN STEWART**
}

When thinking of spurs to hospital development in the first half of the last century, it would be easy to assume that the greatest watershed was provided by the 1946 National Health Service Act. In this article, however, we focus on an earlier and often overlooked piece of legislation, which had a perhaps equally significant impact on the development of hospitals in England and Wales. This was the 1929 Local Government Act, which changed both the ownership and the focus of many of the largest hospitals in the country. As Robert Pinker has observed, the act "radically altered the percentage distribution of hospital beds in the public sector". Such observations notwithstanding, municipal medicine in the 1930s has not received the historical attention it deserves, an omission which this article seeks in part to remedy. ${ }^{1}$ The terms of the act in respect of hospital development were permissive, and the extent to which local authorities acted had a great effect on the way in which their municipal hospital services developed, and hence the beds and facilities available at the time of the nationalization of the health services. The reaction of local authorities to the act, however, depended partly on their own choices, and partly on constraints over which they had less control.

The 1929 act was significant in terms of the development of the health services generally, because it aimed to remove pauperism as a criterion for access to treatment. Other parts of the act overhauled the municipal grant system in favour of a needs-sensitive block grant, and removed or reduced the rates imposed on industrial and agricultural undertakings. The government's commitment to the improvement of municipal services was therefore seen by some as suspect, although it undoubtedly had potential benefits for the municipal health services. There was considerable scope, for example, for the unification of services being provided concurrently under the Poor Law and the Public Health departments of the same local authorities (such as tuberculosis care). ${ }^{2}$ The former were intended

(C) Alysa Levene, Martin Powell and John Stewart 2006

*Alysa Levene, PhD, Department of History, Oxford Brookes University, Oxford OX3 0BP, UK; Martin Powell, PhD, Department of Applied Social Science, University of Stirling, Stirling FK9 4LA, UK; John Stewart, Department of History, Oxford Brookes University, Oxford OX3 0BP, UK.

The authors wish to acknowledge the support of the Wellcome Trust.

${ }^{1}$ Robert Pinker, English hospital statistics, 1861-1938, London, Heinemann, 1996, pp. 78-9. For a discussion of the historiography of interwar municipal medicine, see Alysa Levene, Martin Powell, and John Stewart, 'Patterns of municipal health expenditure in interwar England and Wales', Bull. Hist. Med., 2004, 78: $635-69$.

${ }^{2}$ Historians who have noted the unevenness of health care in the period include Charles Webster, The health services since the war: volume 1, Problems of health care: the National Health Service before 1957, London, HMSO, 1988, pp. 1, 20; W M Frazer, A history of English public health, 1834-1939, London, Ballière, Tindall and Cox, 1950, p. 299; Roger Lee, 'Uneven zenith: towards a geography of the high period of municipal medicine in England and Wales', $J$ Hist. Geogr., 1988, 14 (3): 260-80, p. 260; Norman Wilson, Municipal health services, London, Allen \& Unwin, 1946, pp. 165, 168-70; John Mohan, Planning, markets and hospitals, London and New York, Routledge, 2002, p. 24; George Godber, 'The Domesday Book of British hospitals', Bull. Soc. soc. Hist. Med., 1983, 32: 4-13. 


\section{Alysa Levene, Martin Powell and John Stewart}

to care for paupers; the latter for non-paupers, although in fact, where the Poor Law medical facilities were good, non-paupers might be cared for under this system also. ${ }^{3}$ The 1929 act abolished the Poor Law administrative system and placed its facilities under new Public Assistance Committees (PACs) on the higher tier local authorities (county councils and county boroughs). These were further permitted and encouraged to transfer all health services from the auspices of Public Assistance to Public Health Committees (PHCs), in order that they might be run on a uniform system wherein access was determined by medical need, not poverty. Included in this transfer were hospitals and workhouses previously run by the Poor Law, which might now be "appropriated" (taken over and administered) by Public Health as general hospitals. Dialogue with the local voluntary medical sector was also encouraged, to further promote uniformity and efficiency. As the Ministry of Health noted to Eastbourne Borough Council in 1933, appropriation would bring about a change "from an institution to which people went because they were poor to a hospital to which people went because they were sick". 4

At its height, the Poor Law medical services provided over 90,000 beds in England and Wales - the largest hospital service in the country. The care and facilities offered in such hospitals were highly varied, however, and often of indifferent quality. ${ }^{5}$ Over half of the beds transferred to the county boroughs had been appropriated by 1935, and thirty-seven of the seventy-nine county boroughs in England had made some expenditure under the head of general hospitals as opposed to Poor Law infirmaries and institutions by the end of the financial year 1936/7, the last year of this period for which we have data on council expenditure. ${ }^{6}$ This represented a growth of hospital beds in the public health sector from 15,765 in 1931 , to 30,264 in $1938 .^{7}$ In the latter year, total local authority beds in the public health sector represented 66.8 per cent of the total available in all sectors. ${ }^{8}$ The act can therefore be seen as kick-starting the development of a nationwide public health hospital service.

The significance of the Local Government Act was noted both by those involved in its implementation, and by later commentators. Martin Powell has observed the way in which it was both praised by contemporaries for its far-reaching intentions and outcomes, and also excoriated for the way that it promoted an inequitable development of services. ${ }^{9}$ The Ministry of Health itself claimed in 1929 that the Poor Law medical service had been "incorrectly regarded as operating in isolation [and] gave rise to confusion, inefficiency,

\footnotetext{
${ }^{3}$ Steven Cherry, Medical services and the hospitals in Britain, 1860-1939, Cambridge University Press, 1996, p. 48, states that towards the end of the nineteenth century one-third of entrants to Poor Law infirmaries were non-paupers.

${ }^{4}$ Ministry of Health survey report correspondence, Eastbourne, National Archives, Kew (hereafter NA), MH66/596.

${ }^{5}$ Webster, op. cit., note 2 above, p. 5; Brian Abel-Smith, The hospitals, London, Heinemann, 1964, pp. 50-1, although he states that conditions did improve in the twentieth century, resulting in greater demand (pp. 201-3); Pinker, op. cit., note 1 above, p. 68.

${ }^{6}$ Local government financial statistics, 1936 , London, HMSO, 1936. Two of these boroughs
}

(Kingston-upon-Hull and Blackpool) spent only a nominal amount per head on general hospitals. Evidence from the Ministry's surveys suggests that they did not in fact appropriate an institution, and were perhaps making payments to a neighbouring borough for user rights.

${ }^{7}$ Martin Powell, 'An expanding service: municipal acute medicine in the 1930s', Twentieth Century British History, 1997, 8 (3): 334-57, p. 348.

${ }^{8}$ Pinker, op. cit., note 1 above, pp. 49-50. These figures include the municipal and voluntary sectors, and represent a slight decline in the proportion provided by the public sector towards the end of the interwar period.

${ }^{9}$ Powell, op. cit., note 7 above, pp. 337-40. 


\section{Municipal Hospital Care in English County Boroughs}

and waste of money", a situation which the act was designed to rectify. ${ }^{10}$ In 1934 , the Health Minister stated that when the act was under discussion, "it was made clear that the intention was to give Local Authorities greater freedom in the administration of their services". ${ }^{11}$ The act was thus necessary (for its supporters) on medical, financial and political grounds. Modern commentators such as Dorothy Porter, however, have criticized it for not achieving its unifying aims, while the local government expert William Robson noted in the 1950s that, generally speaking, the act did not go as far as it might have done: "This lone measure ... appears to have exhausted Mr [Neville] Chamberlain's [the Minister of Health in 1929] zeal for reform". ${ }^{12}$ These criticisms may be true, but they do arise partly from the lack of attention to the act and its outcomes by modern writers, and unreasonable expectations of what it could achieve. ${ }^{13}$

This article re-focuses attention on the municipal hospital sector, and quantifies the scale of its development as a result of the 1929 act. It treats appropriation as a process rather than a single event, considering ongoing investment after the transfer to public health. We consider the pattern of development of the county borough public health hospitals over the 1930s, and examine on what grounds it can be explained. These explanatory factors include economics, opportunity, local politics, and alternative provision. The seventy-nine English county boroughs of 1930 were the highest tier of the local authorities, containing a third of the total national population, and holding the greatest array of powers over health provision. ${ }^{14}$ In 1930 they ranged in size and character from large industrial metropolises such as Birmingham, with a population of $1,002,413$, to small county towns with little industry, such as Canterbury (population 24,450). ${ }^{15}$ London was administered separately, and will not be directly considered here. ${ }^{16}$

One of the reasons for the lack of attention to the ongoing process of hospital development is the difficulty of piecing together what happened in individual boroughs. This problem is overcome here by building up a dynamic picture of appropriation using a number of sources (see Appendix). The principal source consists of a highly detailed, yet under-utilized, set of surveys of county borough medical services in the 1930s, from which returns survive for sixty-seven boroughs. The aim of the surveys was to appraise the extent of action under the 1929 Local Government Act (including hospital appropriation, the integration of municipal health services generally, and the extent of dialogue set up with the voluntary hospital sector), and to promote particular actions. Sanctions were limited, but the Ministry might threaten a re-survey, non-approval of loan applications,

\footnotetext{
${ }^{10}$ Ministry of Health general circular on the Local Government Act 1929, NA, MH55/6.

${ }^{11}$ Minister of Health annual report, 1933-4, p. 34.

${ }^{12}$ Dorothy Porter, Health, civilization and the state: a history of public health from ancient to modern times, London, Routledge, 1999, p. 214; William A Robson, The development of local government, $3 \mathrm{rd}$ ed., London, Allen \& Unwin, 1954, p. 85.

${ }^{13}$ See Powell, op. cit., note 7 above, for a developed argument on unrealistic judgements of the outcomes of the Local Government Act.

${ }^{14}$ Stephen V Ward, The geography of interwar Britain: the state and uneven development, London, Routledge, 1988, p. 157.
}

\author{
${ }^{15}$ Local government financial statistics, 1930 , \\ London, HMSO, 1930. \\ ${ }^{16}$ For London's hospital services and the \\ 1929 Local Government Act, see John Stewart, \\ " "For a healthy London": the Socialist Medical \\ Association and the London County Council in the \\ 1930s', Med. Hist., 1997, 42: 417-36; and \\ Gwendoline M Ayers, England's first state hospitals \\ and the Metropolitan Asylums Board, 1867-1930, \\ London, Wellcome Institute of the History of \\ Medicine, 1971.
}




\section{Alysa Levene, Martin Powell and John Stewart}

or the cutting of grants if the borough failed to comply. The surveys were not, therefore, without their agenda, although surveyors frequently praised individuals and developments as well as pointing out deficiencies. Their great merit is that they offer a commentary of change over the course of the 1930s, a pattern hitherto neglected and unquantified. ${ }^{17}$ The appendix sets out the pace of appropriation over the 1930s, based on information in the Ministry surveys, annual borough financial returns, the 1945-6 Ministry of Health/ Nuffield Provincial Hospitals Trust hospital survey of institutional provision as it had been in 1938, Burdett's Hospitals and Charities Yearbook for 1929, and Ministry of Health annual reports. ${ }^{18}$ The combination of quantitative data with qualitative judgements of quality and motivation provide us with a uniquely rounded picture of the changing state of hospital development over the 1930s.

The central question of this discussion on the development of municipal hospitals is why boroughs acted as they did. It seems likely that both choice and constraint played a part. For some boroughs, the course was relatively straightforward, in that they had little opportunity to develop a general hospital. Such constraints were generally of an institutional or a financial nature: the borough lacked the money to invest in a hospital, or it did not inherit an institution which was suitable for development (in some cases, there was no institution to inherit). The constraints acting on boroughs are therefore relatively easy to interpret, although there was sometimes doubt as to the veracity of claims of poverty. Matters of choice are harder to construe, although the survey reports and correspondence allow us to identify several themes. These include the preferences and attitudes of the council, the nature of the relationship with the voluntary hospitals and neighbouring boroughs, and the influence of individual council members and medical officials, particularly Medical Officers of Health $(\mathrm{MOsH})$. Following the discussion of the factors bearing on hospital development, those that can be measured statistically are examined, in order to find any common characteristics of appropriating boroughs, and to test whether we can predict the likelihood that a borough would appropriate. Finally, we address the hospital policy following appropriation by examining the course of expenditure from the revenue and capital accounts.

\section{Constraints:}

\section{The Institutional Legacy}

The biggest constraint working against the development of a municipal hospital policy was that a county borough might not have received an institution in 1929. The old Poor Law Unions, which were abolished under the terms of the act, did not match the boundaries of the local authorities, and ownership of institutions might be disputed where there was an overlap of usership. ${ }^{19}$ Blackpool and Bury, for example, did not inherit an institution

\footnotetext{
${ }^{17}$ This lack of rigorous quantification of change over time has been noted by Powell, op. cit., note 7 above, p. 336.

${ }^{18}$ Local government financial statistics, $1922 / 3$ to 1936/7 (providing information on expenditure, population and rateable values); Burdett's Hospitals
}

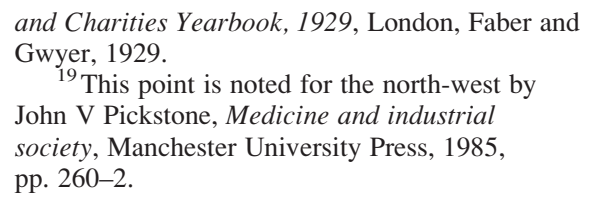




\section{Municipal Hospital Care in English County Boroughs}

because it passed instead to the Lancashire county council. In other cases, another borough was awarded ownership: Wallasey, for instance, did not have an institution because it had been transferred to Birkenhead. As the appendix shows, of the sixty-seven county boroughs with Ministry of Health surveys extant, eight (11.9 per cent) did not inherit an institution in 1929. Such boroughs either had to enter into user arrangements with county borough or county council neighbours, or build, buy or adapt a new hospital. ${ }^{20}$ In the short term at least, therefore, the absence of a transferred institution in 1930 was a constraint to the development of individual boroughs' hospital policies. Other boroughs, meanwhile, inherited several good quality institutions. This facilitated their appropriation as public general hospitals, and the development of proper separation schemes between the chronic and acute sick. Liverpool and Leeds fall into this category.

In other cases, the situation was more complicated because the transferred institution might not have been suitable for appropriation as a separate general hospital. The infirmary might be part of the mixed workhouse, or the two might share facilities such as laundries and kitchens, which would make separation very difficult. The Feetham Institution in Darlington was a mixed one (both workhouse and Poor Law infirmary), with parts of each half lying on either side of a road. The infirmary had been developed piecemeal, and was hard to nurse. The Ministry's surveyor judged that "the Medical Officer of Health is very wise to advise his Council not to sink much capital in it". ${ }^{21}$ In Hastings, the infirmary and workhouse parts of the Public Assistance Institution (PAI) were "so inextricably mixed that separation would be impossible without incurring an unjustifiable expense". ${ }^{22}$

Alternatively, the building itself might be in poor condition, or so old as to make modern facilities hard to install. Aneurin Bevan called the worst of these, "monstrous buildings, a cross between a workhouse and a barracks-or a prison". ${ }^{23}$ In this case it was sometimes deemed more appropriate, by both council and Ministry, to simply build a new general hospital. A borough councillor in Grimsby described the Scartho Road PAI as like the curate's egg, although the surveyor's notes suggest that the bad parts outweighed the good. High levels of overcrowding meant that patients had to be accommodated in the workhouse, or on tables and stretchers on the ward floors. The surveyor noted that the classification of patients was very unsatisfactory, as were the X-ray and laboratory facilities and the anaesthesia room. There was no resident Medical Officer, and the overall impression was of "all-round mediocrity". ${ }^{24}$ An equally unflattering picture was painted of Lincoln's Burton Road PAI, described by the surveyor as "the least satisfactory Poor Law Infirmary which I have yet encountered in a county borough". ${ }^{25}$ Ward floors were uneven and nursing was made difficult by small spaces between the beds. Some wards had radiators projecting into them, along the length of patients' beds. All the wards were overcrowded, and there was no proper classification. The appropriation of this institution was not

\footnotetext{
${ }^{20}$ Stoke, Birmingham, Coventry, Huddersfield, Hull, and Wigan all planned new hospitals in this period. Newcastle, South Shields, and Sunderland made plans to build or expand which were halted by the outbreak of war. Powell, op. cit., note 7 above, p. 343.

${ }^{21}$ Ministry of Health survey report, Darlington, NA MH66/571.
}

\footnotetext{
${ }^{22}$ Ministry of Health survey report, Hastings, NA MH66/665.

${ }^{23}$ Aneurin Bevan, Hansard, House of Commons, 422, 30 April 1946, cols 48-9.

${ }^{24}$ Ministry of Health survey report, Grimsby, NA MH66/645.

${ }^{25}$ Ministry of Health survey report, Lincoln, NA MH66/718.
} 
Alysa Levene, Martin Powell and John Stewart

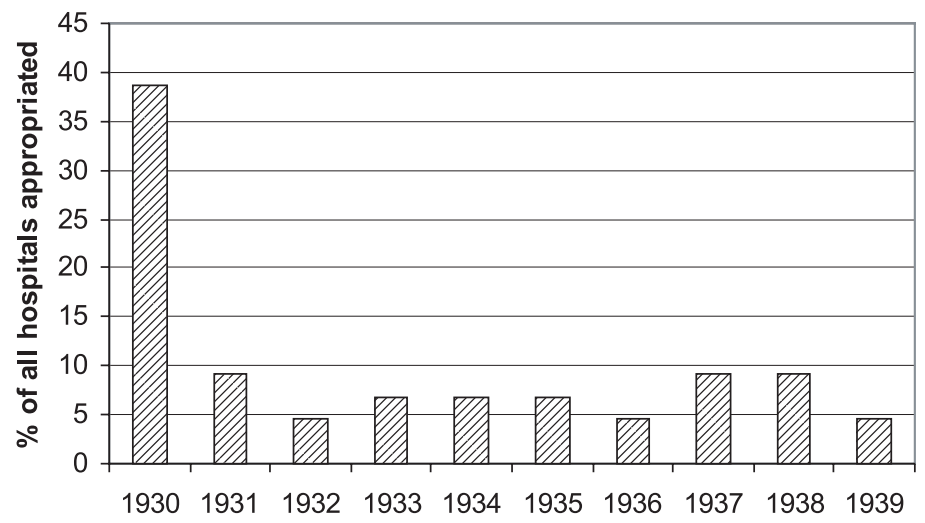

Figure 1: The pace of hospital appropriation, 1930-39.

Sources: Ministry of Health County Borough Surveys, 1930-39, NA MH 66/419-1023. The total number of hospitals with a clear date of appropriation from this source was 44, in 36 county boroughs.

recommended, highlighting the fact that it was not automatically assumed to be the best course of action by the Ministry. Grimsby's Scartho Road was appropriated in 1937, however, after the development of a plan for better classification and other improvements.

The number and state of the inherited buildings, therefore, dictated to a certain extent what could be done with them. The Health Ministry's annual report for 1930-1 noted that the boroughs with separate Poor Law infirmaries had generally appropriated rapidly after 1929, and that the difficulty of separation from the workhouse proved the main obstacle to appropriation elsewhere. ${ }^{26}$ Even where the building could be appropriated, the separation of patients was sometimes problematic. Workhouses frequently accommodated large numbers of chronic and elderly patients, who needed palliative rather than active care, and were often felt to be better off remaining under the PAC rather than the PHC. The Hastings PAI was in such a position, and had not been appropriated by the end of the interwar period. ${ }^{27}$ The pace of appropriation after 1930 shown in Figure 1 supports the Ministry's assertion that suitable buildings were appropriated rapidly, while the others lagged behind until improvements could be made, or reservations overcome. It shows clearly that a large proportion of the total was taken over in the first available year after the act came into force.

\section{The Financial Situation: Budgets and Incomes}

The second constraint acting against appropriation was financial. The question of whether poor boroughs, which might have high needs for a whole range of services, were able to spend at the necessary level has long been debated. The trend of opinion has been that they could not, although the assumption has only recently been subject to

${ }^{26}$ Minister of Health annual report, 1930-1, pp. $51-2$.

${ }^{27}$ Ministry of Health survey report, Hastings, NA MH66/665. The Hastings and East Sussex councils had evolved a scheme whereby the sick from both councils were to be accommodated in the Hastings institution, which could then be appropriated. The scheme was shelved by 1934 , however, and not resurrected. 


\section{Municipal Hospital Care in English County Boroughs}

rigorous statistical consideration. ${ }^{28}$ A parallel part of the current project has been engaged in such a consideration, and has found that investment in hospitals is less explicable in these terms than other branches of health care. This is possibly because the state of the buildings inherited from the Poor Law overwhelmingly shaped investment requirements, at least in the short term. There are undoubtedly instances of poor boroughs being well-off in terms of municipal bed provision. Tynemouth, for example, was a borough with a relatively low rateable value, but a large number of municipal beds per head in 1938 - 7.7 compared to a borough average of 3.9. ${ }^{29}$ Although the evidence suggests that poor areas were less able to spend highly on health generally, therefore, this should not be taken as proof that they were unable or unwilling to invest in their hospitals.

While alert to the fact that some boroughs had lower levels of resources than others, the Ministry tended to condemn authorities which pleaded poverty as dilatory and irresponsible. This exasperation was probably enhanced by the assumption by many authorities that appropriation automatically brought greater expense because of the loss of powers of recovering costs from pauper patients from outside the authority. In fact, as the Ministry tried to impress upon authorities, there should have been very little increase in expense arising from appropriation per se, as long as the council viewed the totality of expenditure rather than worrying about the budgets of specific committees.

This, however, did not stop boroughs from being anxious about higher costs, or at least offering them as the reason for failing to appropriate an institution, as did Barnsley, Bolton, Burton-upon-Trent, and even affluent Eastbourne. ${ }^{30}$ The first three did tend to spend at below average levels per head on many other health services, although Barnsley invested at a high level on maternity and child welfare. Eastbourne was a higher spender on most of the major services, especially mental hospitals. Boroughs which were reluctant to spend on their hospitals were thus not necessarily those which spent at a low level on health generally, although several of the examples given do fall into this category. Gloucester and Blackpool cited their commitments to keeping rates down in defence of their reluctance to spend. ${ }^{31}$ These boroughs were also unremarkable in their expenditure elsewhere in the health field, spending below the average on all the major services. It is perhaps not surprising, therefore, that the Ministry often detected apathy in these pleas for economy, writing of Burton that "the arguments against appropriation are those almost universally employed by Councils who have no intention of improving their hospital services". ${ }^{32}$

\footnotetext{
${ }^{28}$ Martin Powell, 'The geography of English hospital provision in the 1930s: the historical geography of heterodoxy', J. Hist. Geogr., 1992, 18 (3): 307-16, pp. 309-10. Those supporting the assertion that poor boroughs were less able to afford good health care (at least prior to the changed grant system of 1929) include Webster, op. cit., note 2 above, pp. 294-337; J R Hicks and U R Hicks, Standards of local expenditure: a problem of the inequality of incomes, National Institute of Economic and Social Research Occasional Papers, 3, Cambridge University Press, 1943; Brian T Preston, 'Rich town, poor town: the distribution of rate-borne spending levels in the Edwardian city system', Trans. Inst. Br. Geographers, 1985, New Series, 10: 77-94.
}

\footnotetext{
${ }^{29}$ Ministry of Health/Nuffield Provincial Hospitals Trust hospital survey, London, 1945-6.

${ }^{30}$ Ministry of Health survey reports, Barnsley, NA MH66/421, Bolton, NA MH66/459; re-survey correspondence, Burton, NA MH66/507; survey correspondence, Eastbourne, NA MH66/596.

${ }^{31}$ Ministry of Health survey reports, Gloucester, NA MH66/625 and Blackpool, NA MH66/454. The Blackpool council did point out that as a resort town much of their commercial income was concentrated in three months of the year. This may have led to a cautious attitude towards finance, although they were by no means the only borough in this position.

${ }^{32}$ Ministry of Health re-survey correspondence, Burton-upon-Trent, NA, MH66/507.
} 


\section{Alysa Levene, Martin Powell and John Stewart}

In a few cases, however, the Ministry recognized that there was genuine financial distress. This was particularly true of the boroughs in the north-east where Special Area status was accorded by legislation in 1934 recognizing the particular socio-economic problems faced by some parts of the country at the height of the Depression. These boroughs generally had high levels of overcrowding and infant mortality, and also had to support large numbers of unemployed. This made them even less able to invest money in their health services. Poorly-off boroughs were also placed on a secret government "blacklist" in the 1930s, making it very unlikely that they would receive approval for large projects involving loans for capital expenditure. ${ }^{33}$

At the time of its survey in 1931, for example, Gateshead was noted to have an unemployment rate of 30.9 per cent, compared with the national average of 14 per cent. Rate levels were also above average, yet only 7s 10d was spent per capita on public health, compared with an average of 18s. It appeared on "blacklists" throughout the period, and was classed as category B in 1937. This denoted high rates of local taxation, serious and prolonged unemployment, but with some prospect of industrial revival (only Merthyr Tydfil in the South Wales coalfield was categorized as level A, with little or no prospect of industrial revival). ${ }^{34}$ By 1933, Gateshead council was pleading total incapacity without major rate rises, and wrote to the Ministry seeking assistance. The burden of unemployment meant that twice as much was being spent on public assistance as health. ${ }^{35}$ Although the Ministry could in this instance only reassure the council that the nationalization of the unemployment problem was under consideration, they evidently felt that Gateshead had grounds for pleading particular distress. South Shields, also depressed, was privately compared unfavourably to it, for not making the best of a poor situation. ${ }^{36}$ This suggests that the attitude of the borough played a role alongside finances in formulating a convincing defence for low spending levels. It has also been noted that the May and Ray reports of 1931 and 1932 called for decreases in public expenditure, and local authorities may not have been in a position to invest in their new hospitals until 1934 or $1935 .^{37}$

On the other hand, the Ministry claimed a tendency towards "extravagance" on the part of certain borough councils. This not infrequently emerged after a council had dragged its feet over improving a transferred institution, and then produced a lavish scheme to build a new hospital instead. Doncaster, for instance, had protested against the appropriation of Springwell House, but then approved a plan for a new hospital costing $£ 100,000 .{ }^{38}$ Given that the county council was also building a new hospital, the Ministry was not happy to sanction a loan for capital expenditure until active co-operation with the county council and the voluntary hospitals had been ruled out. Gloucester also pursued plans for new maternity accommodation while the Ministry was stressing the need for more urgent reforms. In this

\footnotetext{
${ }^{33}$ Financial position of local authorities, Indebtedness of Local Authorities Committee (1922), NA HLG52/1343; Stephen V Ward, 'Implementation versus planmaking: the example of List $\mathrm{Q}$ and the depressed areas 1922-39', Planning Perspectives, 1986, 1: 3-26.

${ }^{34}$ Financial position of local authorities, NA HLG52/1344-5.
}

\footnotetext{
${ }^{35}$ Ministry of Health survey report and correspondence, Gateshead, NA MH66/619 and 622 .

${ }^{36}$ Ministry of Health survey report, South Shields, NA, MH66/890.

${ }^{37}$ Frazer, op. cit., note 2 above, p. 392.

${ }^{38}$ Ministry of Health survey report, Doncaster, NA, MH66/584.
} 


\section{Municipal Hospital Care in English County Boroughs}

case, it was made clear that sanction would not be given for the maternity hospital loan until the general hospital had been appropriated. ${ }^{39}$ This "extravagance" was despite the borough's self-proclaimed desire to keep the rates down. Clearly the Ministry was not happy to allow boroughs to spend needlessly, or risk lending them money, even in the name of improved hospital facilities.

Other boroughs were constrained by resources in the form of population size. Canterbury, Carlisle, and Dewsbury were all noted by Ministry surveyors to be too small to provide the full range of borough services efficiently given their limited financial resources. ${ }^{40}$ Small population size was another factor cited by Aneurin Bevan as working against appropriation in some authority areas. ${ }^{41}$ Once again, though, it is worth recalling the Ministry's own, correct, assertion that appropriation in itself need not increase costs. What may in fact have been a more pressing preoccupation for many Public Health committees was the swelling of their own outgoings as responsibility for ex-Poor Law hospitals passed over from the Public Assistance committees. It is therefore now appropriate to move on to factors which more directly involve matters of choice and conscious decision.

\section{Choices:}

\section{Politics, Preferences, and Personnel}

It is generally thought that local political parties exerted a substantial influence over expenditure on most ameliorative council services, and that socialist parties were inclined to spend highly in this area. ${ }^{42}$ Notwithstanding the high profile role of the Labour party in the development of London's hospitals, output-study measures of needs, resources and inclination (represented by the strength of the Socialist presence on the council) are not very useful in statistically explaining expenditure on hospitals for the county boroughs. ${ }^{43}$ It is fortunate that the health survey reports permit us a rare insight into such influences. ${ }^{44}$ The surveyors frequently noted the role of individuals, committees, and ideologies in setting the borough's hospital policy. The reports give the distinct impression that personal influences were among the most important in determining the pace and ultimate outcome of appropriation and reform. Certainly, party affiliation was given relatively little weight by the surveyors (or perhaps by their sources of information on the council). In Leeds, the

\footnotetext{
${ }^{39}$ Ministry of Health survey report correspondence, Gloucester, NA, MH66/628.

${ }^{40}$ Ministry of Health survey reports, Canterbury, Carlisle and Dewsbury, NA, MH66/519, 524 and 580

${ }^{41}$ Aneurin Bevan, Hansard, House of Commons, 422, 30 April 1946, cols 48-9.

42 James E Alt, 'Some social and political correlates of county borough expenditures', Br. J. pol. Sci., 1971, 1: 49-62; David N King, 'Why do local authority rate poundages differ?', Public Administration, 1973, 51: 165-73; L J Sharpe and K Newton, Does politics matter? The determinants of public policy, Oxford, Clarendon Press, 1984, pp. 14, 178; Tore Hansen, 'Transforming needs into expenditure
}

decisions', in Kenneth Newton and Frances Pinter (eds), Urban political economy, London, Frances Pinter, 1981, pp. 27-47, on p. 41; Martin Powell, 'Did politics matter? Municipal public health expenditure in the 1930s', Urban Hist., 1995, 22: $360-79$.

${ }^{43}$ On the Socialist Medical Association and the London Labour Party on hospital policy, see Stewart, op. cit., note 16 above, although it is also the case that the early pace in appropriation was set by the Municipal Reform Party.

${ }^{44}$ Powell, op. cit., note 28 above, p. 314 , has noted the influence of wider factors such as local politics and personnel on expenditure decisions. 


\section{Alysa Levene, Martin Powell and John Stewart}

surveyor noted that opposition to appropriation was "largely due to party politics". 45 In Norwich the postponed decision on hospital policy was thought to be "because the political parties, who hold very divergent views on the matter, are about equally represented on the Council". ${ }^{46}$ Generally, however, the surveyors tended to comment more on the attitudes and relationships of councils and their élites than on political persuasion.

In keeping with their lack of patience with boroughs who were thought to be dilatory in their decision-making, the Ministry made short shrift of those whose commitment to the development of hospital care were seen to be wanting. In some cases the Ministry's attitude may have been at least partially justified. Jonathan Bradbury has characterized certain individual boroughs such as Great Yarmouth and Burton as "relatively well off local authorities which also simply opted not to provide good all-round services". ${ }^{47}$ A few actually articulated a reluctance to develop hospital services after 1929. Bournemouth, for instance, stated that they did not need as full a public health provision as other boroughs because of their unique status as a holiday location with an elderly population. The surveyor's response in his report was that "the town is not so exceptional that it can afford to neglect its Public Health services". ${ }^{48}$ All three of these boroughs were dominated by the Conservative party through much of the period. ${ }^{49}$

Other boroughs cited priorities in other fields such as education and slum clearance which the 1929 act was not seen to over-ride. ${ }^{50}$ West Hartlepool claimed that the upkeep of roads had had to take priority because of increased motor traffic. ${ }^{51}$ The Ministry had to threaten West Hartlepool (also a borough with a Conservative majority, although with a growing Labour presence) with a reduction in their grant apportionment if they did not improve their health services and appropriate Howbeck Institution, the only borough council to receive such a threat. ${ }^{52}$ In the re-survey report in 1936, the surveyor wrote that "so far as West Hartlepool is concerned the Local Government Act, 1929 might never have been passed". Despite ongoing exchanges with the Ministry from the date of the first survey in 1932, the council claimed still to be considering its position in May $1939 .{ }^{53}$

\footnotetext{
${ }^{45}$ Ministry of Health survey report, Leeds, NA, MH66/709.

${ }^{46}$ Ministry of Health survey report correspondence, Norwich, NA, MH66/784A.

${ }^{47}$ J P Bradbury, 'The 1929 Local Government Act: the formulation and implementation of Poor Law (health care) and Exchequer grants reform for England and Wales (outside London)', PhD thesis, University of Bristol, 1991, pp. 302-4.

${ }^{48}$ Ministry of Health survey report, Bournemouth, NA MH66/473.

${ }^{49}$ Data on political composition are taken from The Times annual municipal election reports in early November each year. All three boroughs have missing data for part of the period, but the Conservative influence is strong where data were reported. In Burton, this was especially true from 1928 onwards, when the Conservatives took an outright majority, although they had been the largest single party prior to this. John K Walton notes the tendency for politics in resort boroughs to be based on "internecine struggles between interest-groups", reflected here in the comments for
}

Yarmouth and Bournemouth: The British seaside: holidays and resorts in the twentieth century, Manchester University Press, 2000, p. 69.

${ }^{50}$ Ministry of Health survey report and correspondence, Barrow and Bolton, NA MH66/422 and 463.

${ }^{51}$ Ministry of Health survey report, West Hartlepool, NA MH66/988.

${ }^{52}$ Ministry of Health survey report correspondence, West Hartlepool, NA, MH66/991. Labour held a steady 15 per cent of seats up to 1934 , when its representation began to rise, taking a majority in 1937 (The Times municipal election reports).

${ }^{53}$ Ministry of Health survey report correspondence and re-survey report, West Hartlepool, NA, MH66/991 and 993. This lack of action was despite the hope expressed by the council in 1936 that the election of a Labour majority would bring appropriation; one of the few instances where political colour was cited as affecting outcomes. In this case, it ultimately seems not to have had an effect. 


\section{Municipal Hospital Care in English County Boroughs}

Not all councils received such censure however. Labour-controlled Bradford was noted to be very interested in developing its health services to a high standard, and had in fact been running its hospitals under a unified public health scheme since the end of the Great War. ${ }^{54}$ The Local Government Act therefore had little practical effect in this borough either, but here because its terms had already been adopted. ${ }^{55}$ Croydon also received praise for its efforts to remove all aspects of health care from the Poor Law. The Mayday Hospital was appropriated in 1932, which the Ministry actually referred to as "comparatively late", although it was one of only twenty-two boroughs spending under the head of general hospitals in the financial year 1931/2. ${ }^{56}$ Kingston-upon-Hull was noted to have developed a cohesive hospital scheme, whereby the Anlaby Road Institution was to be converted and appropriated solely for the sick, while the less impressive Beverley Road Institution was to house the poor and destitute. ${ }^{57}$ An advantage of this scheme in the eyes of the Ministry was that it could be implemented in stages, reinforcing their contention that appropriation need not entail a large outlay for the council.

Individuals and groups on the council could also exert a strong influence for or against hospital appropriation and development. The Medical Officer of Health was an obvious case in point. ${ }^{58}$ In Bristol the $\mathrm{MOH}$ was said to be a man of ingenuity and diplomacy who had the courage to face opposition, and in Manchester, Dr Veitch Clark (later one of the 1945-6 hospital surveyors) spearheaded improvements in health care. ${ }^{59}$ In other cases, though, the MOH found himself excluded by Public Assistance officials from involvement in the transferred medical services. Surveyors not infrequently discovered that the MOH was not allowed free access to the Public Assistance institution, either because of jealousy from the Public Assistance officers, or because the MOH had (inadvertently or otherwise) caused offence. In Barnsley a poor relationship between the PAC and the previous $\mathrm{MOH}$ resulted in the new incumbent being allowed little involvement with the transferred institution. ${ }^{60}$ In Doncaster the MOH was an elderly man who had "exercised an excessive zeal for economy". ${ }^{61}$ Generally, the $\mathrm{MOH}$ claimed to be in favour of appropriation and where he was a dynamic and diplomatic man, and his council concurred with him, he was able to carry the day. In other cases, personal weakness or intransigent opposition left MOsH unable or unwilling to fight their corner. Much of the resistance of the Public Assistance officials can be attributed to fear of losing a perhaps soon-to-be modernized institution, leaving them with only the aged and chronic cases. As we have seen, this was in its own terms a perfectly legitimate fear.

\footnotetext{
${ }^{54}$ Ministry of Health survey report, Bradford, NA, MH66/477. Labour held an average of 40 per cent of council seats in Bradford throughout the period (The Times municipal election reports).

${ }^{55}$ The Ministry of Health/Nuffield surveys of 1945-6 also noted the progressive stance of Leeds and Bradford in the health field. Powell, op. cit., note 7 above, p. 345, also cites examples of boroughs which had well-developed hospitals in 1929.

${ }^{56}$ Ministry of Health survey report, Croydon, NA, MH66/564.

${ }^{57}$ Ministry of Health survey report, Kingstonupon-Hull, NA, MH66/685.
}

\footnotetext{
${ }^{58}$ Wilson, op. cit., note 2 above, pp. $170-1$. Webster, op. cit., note 2 above, p. 8 , notes the role of the $\mathrm{MOH}$ in setting the standards of municipal health care generally. Jane Lewis, What price community medicine? The philosophy, practice, and politics of public health since 1919, Brighton, Wheatsheaf, 1986, also highlights the increased profile of MOsH.

${ }^{59}$ Ministry of Health survey report, Bristol, NA, MH66/487; Pickstone, op. cit., note 19 above, p. 259.

${ }^{60}$ Ministry of Health survey report, Barnsley, NA, MH66/419.

${ }^{61}$ Ministry of Health survey report, Doncaster, NA, MH66/584.
} 


\section{Alysa Levene, Martin Powell and John Stewart}

Antagonism between the Public Assistance and Public Health committees was the most frequent cause of discord on councils. This was especially true where the former were mainly ex-Poor Law Guardians, often champions of the status quo and reluctant to give up responsibility for "their" institutions. ${ }^{62}$ In Blackburn, former Guardians vigorously opposed appropriation. The surveyor for Oxford likewise attributed the lack of progress in the transfer of health functions to the PAC chairman, an ex-Guardian who saw no need for change. ${ }^{63}$ It was said of Stockport that the 1929 act was "a dead letter; the old Guardians still reign supreme" while in West Hartlepool the council was "undoubtedly very dilatory, and as there is a fairly strong contingent of the old Guardians on the Public Assistance Committee they are rather prejudiced against altering the present arrangement". 64 The reluctance of the PAC to allow change is a recurrent theme in the survey reports, and was sometimes alluded to by the public health officials themselves. An intransigent PAC could be a powerful force delaying appropriation, and we may count it as one of the most influential factors working against the adoption of a municipal hospital policy.

It was common for different parts of the council to maintain jealous independence from each other. The Minister of Health noted in his annual report for 1932-3 the tendency for councils to regard "particular problems as the problems only of a single committee". ${ }^{5}$ The surveyor for Barrow-in-Furness summed the situation up when he wrote that "political theories have prevailed which stress rather the form of control than the attainment of the greatest good for the greatest number through the co-operative use of all the available material and personnel" ${ }^{66}$ Barrow was a Labour-dominated borough for most of the period. Despite the influence of a supposedly "progressive" force for change, however, the existence and results of intra-council struggles gives further credence to the relative lack of significance of traditional explanations for investment in health care. Blackburn's failure to unite the Public Assistance and Public Health committees was "explained, though not excused, by a self-seeking and unenlightened individualism operating in members of both council and staff". ${ }^{67}$ In Gloucester, the surveyor commented that appropriation might have taken place if only the PHC had pursued the aim with greater enthusiasm, and the PAC with less apprehension. ${ }^{68}$ Elsewhere, thought had been given to the structure of the committees, but they had been allowed to grow overly large and unwieldy. ${ }^{69}$ The large number of boroughs appropriating in 1930, as seen in Figure 1, indicates that this antagonism was not universal. However, the appendix shows that many boroughs did delay appropriation, or never put it into practice, and poor relations on the council were one of the most frequently cited reasons.

\footnotetext{
${ }^{62} \mathrm{~J}$ M Mackintosh, Trends of opinion about the public health, 1901-51, London, Oxford University Press, 1953, p. 132, wrote that "it is difficult to overestimate the enthusiasm with which the new Public Assistance Committees set about their task of transforming the old institutions and reclassifying their inmates". This picture is not borne out by the Ministry surveys, although they of course had an interest in removing the hospitals from the PACs in favour of the PHCs.

${ }^{63}$ Ministry of Health survey reports, Blackburn and Oxford, NA, MH66/450 and 805.
}

\footnotetext{
${ }^{64}$ Ministry of Health survey reports, West Hartlepool and Stockport, NA, MH66/988 and 898.

${ }^{65}$ Minister of Health annual report, 1932-3, p. 35 .

${ }^{66}$ Ministry of Health survey report, Barrowin-Furness, NA, MH66/422.

${ }^{67}$ Ministry of Health survey report, Blackburn, NA, MH66/450.

${ }^{68}$ Ministry of Health survey report, Gloucester, NA, MH66/625.

${ }^{69}$ Ministry of Health survey reports, Derby and Oxford, NA, MH66/577 and 805.
} 


\section{Municipal Hospital Care in English County Boroughs}

\section{The Provision of the Voluntary Hospitals}

While infighting on the council might delay or prevent hospital reform, another voice was sometimes heard in the form of the voluntary sector. As noted, one of the aims of the Local Government Act was to promote dialogue between the municipal and voluntary sectors. Although the voluntary hospitals were administered separately, funded in a different way, and often catered for different people, Ministry surveyors were anxious to promote a unified policy with the newly transferred municipal hospitals. This was part of a general policy towards increased co-operation between the hospital sectors, voiced also by Viscount Sankey to the Voluntary Hospitals Commission in $1935 .^{70}$ The Minister of Health's annual report for 1933-4 likewise stressed that the overcoming of differences between the sectors was "one of the most valuable contributions to the cause of public health and the interests of the sick which can be made by those locally responsible for these services". ${ }^{71}$ General policy dictated that municipal hospitals should not compete with existing provision, and in certain areas it was decided that appropriation should not be pressed as the voluntary hospital was carrying out all the acute medical and surgical work that needed to be done. In these cases it might be recommended that the municipal hospital fulfil only a limited role under the PHC, or that it remain under Public Assistance. ${ }^{72}$ The nature of the relationship with the voluntary hospital therefore has elements of both choice and constraint in the effect it had on the development of the municipal sector.

It has been noted elsewhere that voluntary hospital beds were not evenly distributed around the country, as they, like the more specialist consultant services, tended to be concentrated in areas which could support the private work of their (unpaid) doctors. ${ }^{73}$ The relationship between voluntary and municipal hospitals therefore varied significantly from one borough to another, making it difficult to assess in any quantitative sense. We are thus fortunate that the surveyors were directed to comment on this significant influence on hospital policy. In many cases it was clear that a borough could support both municipal and voluntary hospitals offering a full range of services, but in others a unified service would depend on careful and sensitive negotiation. In some cases this was forthcoming at the instigation of the council, especially where there was an overlap of personnel in the two sectors. ${ }^{74}$ Chester is perhaps the best example, where the council devised a plan to transfer all their hospital services to the voluntary sector along with an annual grant, in return for representation on the hospital board. The surveyor was dubious as to the feasibility of this plan, and in fact it was never implemented. Its justification was given in a comment made to the surveyor by the Town Clerk, that "the [voluntary] Royal Infirmary was regarded as the most important factor in the public health work of the town and that it was essential that

\footnotetext{
${ }^{70}$ Daniel Fox, Health policies, health politics: the British and American experience, 1911-1965, Princeton University Press, 1986, pp. 58-9.

${ }^{71}$ Minister of Health annual report, 1933-4, p. 57.

${ }^{72}$ For example, in Carlisle, Bournemouth, Gloucester, Ipswich and Wigan, municipal hospital provision was not developed into general and acute work, as this was adequately provided by the voluntary
}

sector. Ministry of Health survey reports, NA, MH66/ 524, 473, 625, 693 and 1003.

${ }^{73}$ Powell, op. cit., note 28 above, p. 309; Martin Gorsky, John Mohan and Martin Powell, 'British voluntary hospitals, 1871-1938: the geography of provision and utilization', J. Hist. Geogr., 1999, 25: 463-82, pp. 464, 468-9, 474; Abel-Smith, op. cit., note 5 above, pp. 405-7.

${ }^{74}$ Abel-Smith, op. cit., note 5 above, pp. 380-1. 


\section{Alysa Levene, Martin Powell and John Stewart}

at all costs this institution should be saved from rival competition and from the loss of voluntary subscriptions owing to the existence of a separate rate-aided hospital". 75

Such a perspective was unusual among the county boroughs. Instead, they tended to adopt the somewhat negative strategy of not developing their own services when faced with adequate alternative provision rather than actively turning control over to the voluntary sector. In some cases, though, it was the voluntary hospital which was struggling, and the municipal hospital was used to relieve overcrowding or lengthy waiting lists. In Barnsley, the appropriation of the Gawber Road Hospital was encouraged partly for this reason. Since there were no consultants attending at the municipal hospital, however, an arrangement between the two sectors was likely to benefit both. The surveyor noted that it would be very expensive to modernize Gawber Road, but that "if the development is carefully carried out in close consultation with the voluntary Authorities... the expenditure is likely to be justified by the results". ${ }^{76}$ In Great Yarmouth it was felt that active co-operation with the voluntary hospital was the only way to provide comprehensive facilities in the borough. ${ }^{77}$ The PAI was judged by the surveyor not to be worth developing, while a new municipal hospital would be expensive, and probably lead to the ultimate failure of the voluntary hospital. The PAI was not appropriated, and the Ministry of Health/Nuffield hospital survey recorded that all the general beds in the borough were provided by the voluntary sector while the chronic beds were municipally funded. ${ }^{78}$ This suggests that the borough did indeed consider the voluntary provision when developing a hospital policy.

Elsewhere, the distinction between a cohesive policy and apathy in the face of adequate voluntary facilities is less clear. The 1945-6 surveyors noted that dialogue was often not forthcoming. Those for Yorkshire wrote of the common "suspicion of the aims of the "other side" which has tended in many districts to make an approach on a basis of mutual confidence difficult". ${ }^{79}$ We also cannot be certain whether beds in the two sectors were of comparable quality. Oxford, for example, has been characterized as being uninterested in developing its municipal services in this period, and it did not appropriate an institution despite the urging of the Ministry. ${ }^{80}$ In 1938 it had only 0.6 medical municipal beds per thousand (excluding Public Assistance beds), compared with a borough average of 3.9. Its voluntary bed provision was such, however, that its overall bed levels were above average, at 10.1 compared with 7.9. Bath was in a similar position, with 1.0 medical municipal beds, but a total bed provision of 14.4 per thousand. In these cases, the council may not have seen itself as being the primary provider of hospital care in the city and therefore as having little incentive to pursue appropriation. Although the balance of hospital provision between the voluntary and municipal sectors varied from borough to borough it does seem to have exerted an important influence in the form that council hospital services took.

\footnotetext{
${ }^{75}$ Ministry of Health survey report, Chester, NA, MH66/537.

${ }^{76}$ Ministry of Health survey report, Barnsley, NA, MH66/419. Appropriation took place four years later.

${ }^{77}$ Ministry of Health re-survey report, Great Yarmouth, NA, MH66/642.

${ }^{78}$ Ministry of Health/Nuffield Provincial Hospitals Trust hospital survey, London,
}

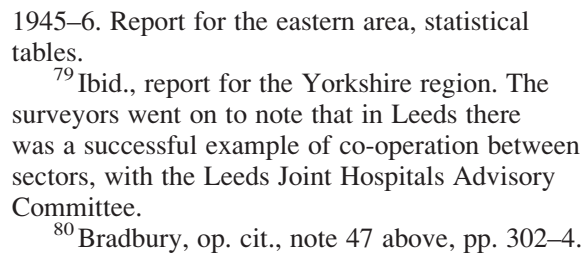


The extent of voluntary provision in the borough evidently affected the development of municipal hospitals. So too did the level of provision, both municipal and voluntary, in neighbouring boroughs. Although county boroughs were technically self-supporting in their municipal health provision, smaller boroughs sometimes reflected natural regional hierarchies by entering into user arrangements with a nearby hospital rather than building several uneconomically small institutions. ${ }^{81}$ Thus a borough which did not develop its own hospital policy may still have improved its services via such agreements, especially with regard to specialist services. ${ }^{82}$ This is a further reminder that in economic terms a developed municipal hospital sector was sometimes beyond the resources of smaller boroughs. The wide catchment areas of voluntary hospitals in some of the larger towns and cities may also have had an impact on a smaller borough's inclination or need to develop municipal hospital services. ${ }^{83}$ Surveyors explicitly noted dependent relationships between small boroughs and larger neighbours, across both municipal and voluntary lines: "Considering its size, Bolton has less well-developed specialist services than might have been expected. Probably this is due to proximity to Manchester". ${ }^{84}$ In Coventry, the proximity of Birmingham "no doubt accounts in part for the relatively limited growth in the county of general hospital services, particularly of consultant standard". ${ }^{85}$ Similar comments were made of Oldham, Bootle and South Shields, with regard to their neighbouring large citiesManchester, Liverpool, and Newcastle, respectively. ${ }^{86}$ Several of these boroughs were noted as simply too small to be self-reliant for all aspects of hospital care. As John Mohan remarks, however, access was as important as proximity in determining patient usage of hospitals. Gateshead residents, for example, had much greater ease of access to Newcastle's hospitals than those from Tynemouth. ${ }^{87}$

Certain forms of relationship between neighbours may thus have influenced the development of municipal services. But not all neighbourly relations were harmonious. In the West Midlands, Smethwick did not have an institution of its own and shared the Hallam hospital in West Bromwich with that borough. Superficially, then, co-operation was the order of the day. However, as the Birmingham surveyor recorded: "Unfortunately the antagonism between Smethwick and West Bromwich appears to render this impossible to

\footnotetext{
${ }^{81}$ See Pickstone, op. cit., note 19 above, passim, on the existence of sub-regional hierarchies in the Manchester region.

${ }^{82}$ An example is the Poole Joint Sanatorium for TB patients, which was subscribed to by the county boroughs of Darlington, Gateshead, Middlesbrough, South Shields, Sunderland and West Hartlepool.

${ }^{83}$ Information on the geographical origins of patients collected by the 1945-6 Ministry of Health/ Nuffield Provincial Hospitals Trust hospital survey bears this out. While generally over 90 per cent of patients at the municipal hospitals were from the borough, sometimes half of those attending the voluntary hospitals were from outside. In Sunderland, for example, 43.4 per cent of inpatients at the voluntary hospitals were from the borough, compared
}

with 98.9 per cent at the municipal medical institutions. Even in Preston, where the catchment area for the municipal hospitals appears to have been wider, 56.3 per cent of the voluntary hospital's inpatients were from the borough, compared with 76.7 per cent at the municipal hospital. Ministry of Health/ Nuffield Provincial Hospitals Trust hospital survey, London, 1945-6, statistical information for the north-eastern and north-western areas.

${ }^{84}$ Ibid., north-west, p. 58.

${ }^{85}$ Ibid., West Midlands, p. 27.

${ }^{86}$ Ibid., north-west, p. 64; Ministry of Health survey report, Bootle and South Shields, NA, MH66/466 and 890.

${ }^{87}$ Mohan, op. cit., note 2 above, pp. 28-30. 


\section{Alysa Levene, Martin Powell and John Stewart}

accomplish". ${ }^{88}$ West Bromwich's small size and proximity to Birmingham made it natural to look to the larger city as the local centre for hospital purposes, yet it was left in charge of a large institution of its own. In 1931 only 49 per cent of patients at the Hallam hospital were from West Bromwich. ${ }^{89}$ In this region, boroughs were forced by their size and density to look to each other for hospital accommodation, but local feeling worked against genuine co-operation. A similar rivalry existed between Gloucester and Bristol, making Gloucester reluctant to stand obliged to its larger neighbour. ${ }^{90}$ Relations with neighbours clearly affected hospital policies. Size and proximity to a very large city such as Manchester might result in stunted hospital schemes in the smaller boroughs, while the lack of correspondence between local authority and Poor Law union boundaries threw otherwise independent authorities together in unsatisfactory relationships. Despite the theoretical self-sufficiency of county borough services, the dependence on larger authorities was arguably a characteristic of inter-war health care provision more generally. ${ }^{91}$

\section{Explaining Patterns of Appropriation}

The different local factors discussed above all had a bearing on whether a hospital was appropriated. In this section, we are interested to discover whether there are any characteristics which separated those boroughs which appropriated from those which did not; that is, can we predict which boroughs were more likely to take this action than others? Several of the influences stressed in the Ministry of Health surveys are difficult to quantify, such as local personalities and politics. Others, such as the amount of voluntary provision, proximity to neighbouring boroughs, and more traditional explanatory variables such as population and wealth, may be tested statistically.

Table 1 indicates a number of quantifiable characteristics for the boroughs which spent under the heading of general hospitals in 1936/7, and those which did not. Boroughs which did not inherit an institution in 1930 are excluded. In order to produce a more detailed picture of change over time, we also consider early (up to and including 1933) and late (1934 or later) appropriators. We see that there is no appreciable difference in wealth (rateable value and block grant income) between appropriators and non-appropriators, so endorsing the Ministry's contention that poor boroughs could not plead special circumstances. Poorer boroughs may also have benefited enough from the needs-based block grant that they were not disadvantaged in this respect. The late appropriators had a marginally lower rateable value than the non- and early-appropriators, but their block grant was also slightly lower, suggesting that their other needs indicators were low. ${ }^{92}$

There is, though, a clear distinction between appropriators and non-appropriators in terms of size. The boroughs which appropriated were significantly larger than those which did not, and those which appropriated early tended to be the largest of all. There may have

\footnotetext{
${ }^{88}$ Ministry of Health survey report, Birmingham, NA, MH66/442.

${ }^{89}$ Ministry of Health survey report, West Bromwich, NA, MH66/977.

${ }^{90}$ Ministry of Health survey report, Gloucester, NA, MH66/625.

${ }^{91}$ Fox, op. cit., note 70 above, pp. 29-30.
}

\footnotetext{
${ }^{92}$ The factors involved in calculating the block grant apportionment consisted of rateable value, proportion of the population under five, and the level of unemployment. Norman Chester, Central and local government, London, Macmillan, 1951, pp. 125-8, 288-307; J M Drummond, The finance of local government, London, Allen \& Unwin, 1962, pp. 101-10.
} 
Municipal Hospital Care in English County Boroughs

Table 1

Mean Values of Characteristics for Appropriating and Non-Appropriating Boroughs, 1936-38

\begin{tabular}{|c|c|c|c|c|}
\hline & $\begin{array}{c}\text { Non- } \\
\text { Appropriators }\end{array}$ & $\begin{array}{c}\text { Early } \\
\text { Appropriators }\end{array}$ & $\begin{array}{c}\text { Late } \\
\text { Appropriators }\end{array}$ & $\begin{array}{c}\text { Total } \\
\text { Appropriators }\end{array}$ \\
\hline Rateable value per thousand $(\mathfrak{f})$ & 7.1 & 7.1 & 6.7 & 7.0 \\
\hline Block grant per thousand $(\mathfrak{f})$ & 943.5 & 946.8 & 928.6 & 942.8 \\
\hline Population (thousands) & 95.0 & 264.1 & 179.2 & 245.3 \\
\hline $\begin{array}{l}\text { Labour representation (\% of } \\
\text { council seats) }\end{array}$ & 34.0 & 37.6 & 39.6 & 38.1 \\
\hline $\begin{array}{l}\text { IMR (deaths under one year per } \\
\text { thousand live births) }\end{array}$ & 61.0 & 64.4 & 67.4 & 65.1 \\
\hline Voluntary beds per thousand & 3.3 & 2.3 & 2.3 & 2.3 \\
\hline $\begin{array}{l}\text { Average number of other } \\
\text { boroughs in a ten-mile radius }\end{array}$ & 0.9 & 1.5 & 1.8 & 1.5 \\
\hline $\begin{array}{l}\text { Expenditure per head on health } \\
\text { (excl. hospitals) (f) }\end{array}$ & 511.8 & 543.0 & 567.2 & 548.4 \\
\hline $\mathrm{N}$ & 35 & 28 & 8 & 36 \\
\hline
\end{tabular}

Note: the boroughs which did not have an institution transferred to them under the 1929 Local Government Act are not included in the above table.

Sources: Rateable value, population figures and appropriation dates from Local government financial statistics, 1936, London, HMSO, 1936; Labour representation figures calculated from The Times municipal election returns for 1935; voluntary bed information from Ministry of Health/ Nuffield Provincial Hospitals Trust, The hospital surveys, London, 1945-6.

been several reasons for this. Firstly, larger boroughs were more likely to have more than one municipal institution transferred to them under the 1929 act, making it probable that at least one would be suitable for appropriation. The appendix shows that this was the case for many of the larger boroughs, such as Manchester, Liverpool, and Leeds. Owning several institutions also facilitated classification schemes whereby the chronically sick and the elderly might be housed separately under PAC control. ${ }^{93}$ Further, large cities may have been seen as more prestigious places to work for medical personnel, making it more likely there would be an efficient $\mathrm{MOH}$ to oversee appropriation. It is also likely that large populations could better support a full range of hospital services and consultants.

There was very little to distinguish the different groups of boroughs in terms of political complexion, indicating that Labour presence alone did not promote appropriation. The common indicator of health needs, the infant mortality rate (IMR), was slightly higher among appropriating boroughs, and particularly the late appropriators. There is little intuitively to connect the IMR with hospital need, but high IMRs were associated more generally with overcrowding and poor environmental conditions, reflecting the

\footnotetext{
${ }^{93}$ The hospitals owned by the Metropolitan Asylums Board (MAB) facilitated such specialization of institutions once appropriated. The number and generally good quality of the MAB institutions meant that the London County Council (LCC) was able to
}

appropriate them rapidly, and create a hierarchy of functions. Ayers, op. cit., note 16 above, pp. 240-1. It was an advantage noted by contemporary health officials in London also. See Stewart, op. cit., note 16 above, p. 426. 
economic structure and population density of the borough. The amount of voluntary provision, however, does highlight a notable distinction between boroughs which appropriated and those which did not. Appropriating boroughs had a lower number of voluntary beds per capita, supporting Powell's finding that municipal provision was higher in areas which lacked voluntary facilities. ${ }^{94}$ There was no difference between those which appropriated earlier or later. The prevalence of voluntary hospital finance schemes such as workplace contributory plans may also have impacted on the need for municipal hospital provision for the working classes, and would be deserving of further consideration in a local context. None the less, the findings presented here suggest that voluntary provision may have been considered in policy formulation, as advocated by the 1929 act.

The effect of neighbouring provision was considered by measuring the number of other boroughs in a ten-mile radius. ${ }^{95}$ Contrary to the expectation that boroughs with close neighbours might not appropriate their own hospital, the non-appropriators were more isolated than the boroughs which appropriated hospitals. Boroughs in close proximity to borough neighbours, in areas around Liverpool, Manchester, Birmingham, Leeds, and Bradford, were slightly more likely to be late appropriators. This might indicate that they waited to see what happened nearby before formulating their own policy, or that they needed greater prompting from the Ministry of Health before they themselves appropriated. The final measure considered is of expenditure per capita on other municipal health services. Appropriating boroughs did spend more per capita, suggesting that they were "progressive" in health matters generally, but late appropriators spent more than those who took over general hospitals by 1933. This is again somewhat counter-intuitive, since one might speculate that more "progressive" boroughs might implement the terms of the Local Government Act early on.

These findings were investigated further using regression analysis. ${ }^{96}$ The effect of all the above variables was measured both singly and in conjunction to assess their impact on whether boroughs appropriated or not. In all cases, population size was the only variable whose effect on appropriation was statistically significant when holding other variables constant (that is, that we can be at least 95 per cent certain that its effect was not produced by chance). In order to explore the nature of this effect in greater detail, a variable was also devised which indicated whether a borough inherited more than one institution in 1929. This variable did not have a significant effect on appropriation, but took on greater significance when population size was held constant. This suggests that owning more than one institution did indeed have an effect on the propensity to appropriate but that it

\footnotetext{
${ }^{94}$ Powell, op. cit., note 28 above, p. 314, idem, 'Hospital provision before the NHS: territorial justice or inverse care law?', J. soc. Policy, 1992, 21: $145-63$, p. 159.

${ }^{95}$ Ten miles was chosen to avoid any suggestion of the large cities of Manchester and Liverpool impacting on each other. It is worth considering that neighbouring county councils may have played a part also, but they are beyond the scope of the current study.

${ }^{96}$ The models were all binary logistic ones, treating appropriation as the dummy "yes/no" dependent variable. Since population was the only significant variable (making appropriation more likely), several
}

models were run, in order to probe its effect more closely. The variable was treated variously as continuous and categorical, and the variable denoting ownership of more than one institution was also included in both of these forms in different models. All the models were able to explain at least 40 per cent of the variation in the dependent variable, almost all of which was provided by the population variable. In all cases, population size, whether treated continuously or categorically, was significant at a 95 per cent level or higher. In all cases, ownership of more than one institution was the next most significant variable, although it never attained statistical significance. 


\section{Municipal Hospital Care in English County Boroughs}

was still mediated through population size. Regression analysis therefore supports the assertion that population was the only clearly significant influence on the decision to appropriate of the variables measured here. We must conclude that statistical analysis supports the notion of the importance of economies of scale and feasibility in explaining appropriating behaviour, but that this was not directly related to the likelihood that the borough had inherited multiple institutions.

\section{Continued Patterns of Investment}

We have thus gone some way to explain the static event of hospital appropriation, using a variety of quantitative and qualitative data sources. This final section treats appropriation only as the start of a dynamic process. A borough which appropriated and then invested very little in a hospital cannot be said to have had the same attitude towards hospital policy as one which increased its investment significantly in subsequent years. As Powell has noted elsewhere, appropriation of itself did not improve a hospital. ${ }^{97}$ We therefore now examine appropriation as the beginning of a process to create better hospitals, rather than a single event.

Generally speaking, the boroughs which appropriated fell into two groups: steady spenders, and larger-scale investors. The steady spenders showed a relatively low level of change in revenue expenditure per thousand population from year to year compared to the borough average (capital expenditure is considered separately below). The larger-scale investors, in contrast, showed peaks of investment in certain years. Within these groups, however, some boroughs spent at a high level, and some did not. Of twenty-nine boroughs with at least three years' data on hospital expenditure by 1936-7, eight were steady, low spenders throughout the rest of the interwar period (Southampton, Reading, Newcastle, Middlesborough, Bristol, Southport, Coventry, and Leicester). Four other boroughs (West Bromwich, Halifax, Bradford, and Plymouth) did not particularly increase their expenditure on hospitals over the period, but were steady, high spenders. We may argue that there was a considerable difference between these boroughs in terms of hospital policy: although neither group substantially increased their financial commitment over the period, the latter spent considerably more on their hospitals than the former. It is possible that some hospitals did not need as much investment as others, but the former group spent at a below average level throughout the period.

The larger-scale investors may also be distinguished according to spending pattern. Southend, Warrington, Derby, Croydon, Smethwick, and Leeds showed significantly increased outlay in the first year after appropriation (rapid investors). This suggests that they began to develop their hospitals immediately, and continued to spend at a raised level for the rest of the period. A second group showed a steady outlay for several years, before receiving a boost (the later investors). These boroughs-Rochdale, Birmingham, Sunderland, Liverpool, Oldham, and Sheffield - apparently waited several years before starting to expand their hospital profile, perhaps through lack of inclination, finance or need. A final group maintained a steady upward trend, with fewer definable peaks (the steadily increasing investors), and was constituted by Manchester, Birkenhead, Preston,

${ }^{97}$ Powell, op. cit., note 7 above, p. 345 . 
Alysa Levene, Martin Powell and John Stewart

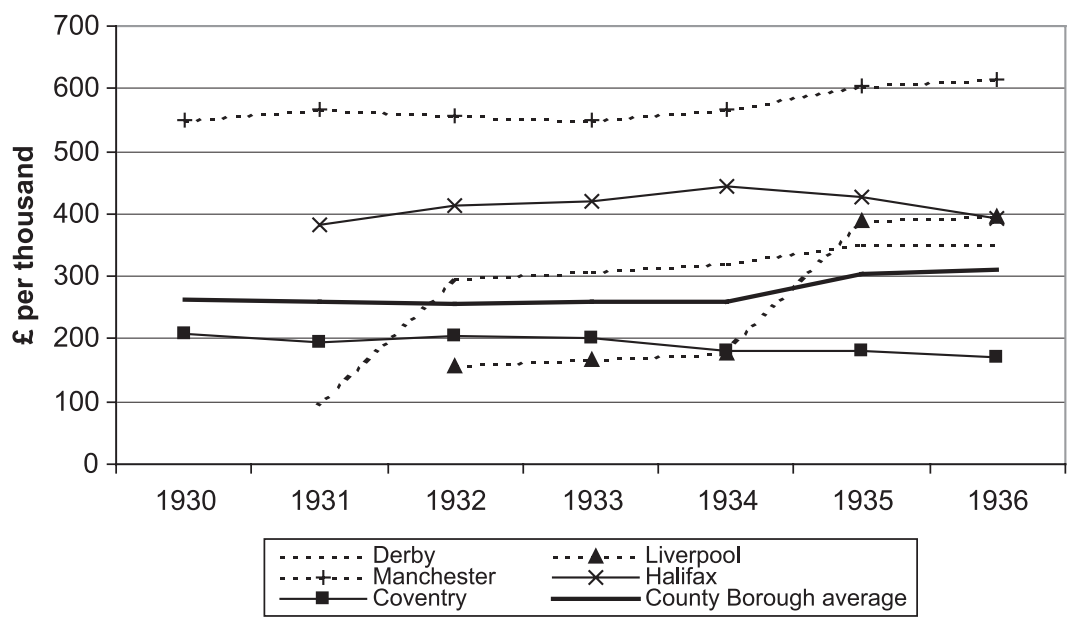

Figure 2: Investment from revenue accounts on general hospitals by selected county boroughs, 1930-36.

Source: Local government financial statistics, 1930-36.

Portsmouth, and Burnley. Given the generally deflationary trend of the interwar period, this slow increase was almost certainly indicative of gradually improving services. Boroughs from each of these five groups are illustrated in Figure 2: Halifax represents the steady high spenders, Coventry the steady low spenders, Derby the rapid investors, Liverpool the later investors, and Manchester the steadily increasing investors. Through these illustrative examples, we may see the different ways in which boroughs responded to the demands and possibilities of hospital appropriation.

It is equally instructive to consider the course of capital expenditure. This may more accurately reflect the investment needed to update hospital buildings after the transfer to public health, rather than the inclination of a borough to prioritize health. It should be remembered, however, that the calls for economy in the 1930s led to a curtailment of building activity, while Ministry "blacklists" prevented poorer boroughs from getting sanction for loans. Figure 3 shows the capital expenditure figures per thousand population for the same illustrative boroughs. The two boroughs representing steady spenders (Halifax and Coventry) both invested more in capital projects early in the period than their constant level of revenue expenditure would suggest, and were either at or above the county borough average. It is possible, however, that these boroughs were committed to capital outlay under the Poor Law, which the PHC merely took over. Since the capital investment did not bring increased revenue expense, we may speculate that it did not consist of additional new buildings (which would bring increased lighting, heating and staff costs), but instead represented improvements to wards or equipment, or building work to replace poor-quality capital. Facilities may therefore have improved, but bed numbers would be unlikely to have increased significantly. The steady revenue expenditure may therefore mask significant outlay in terms of capital, a fact which is particularly notable in the case of Coventry, which spent at a low level. Derby, the early investor, matched its revenue outlay with capital 
Municipal Hospital Care in English County Boroughs

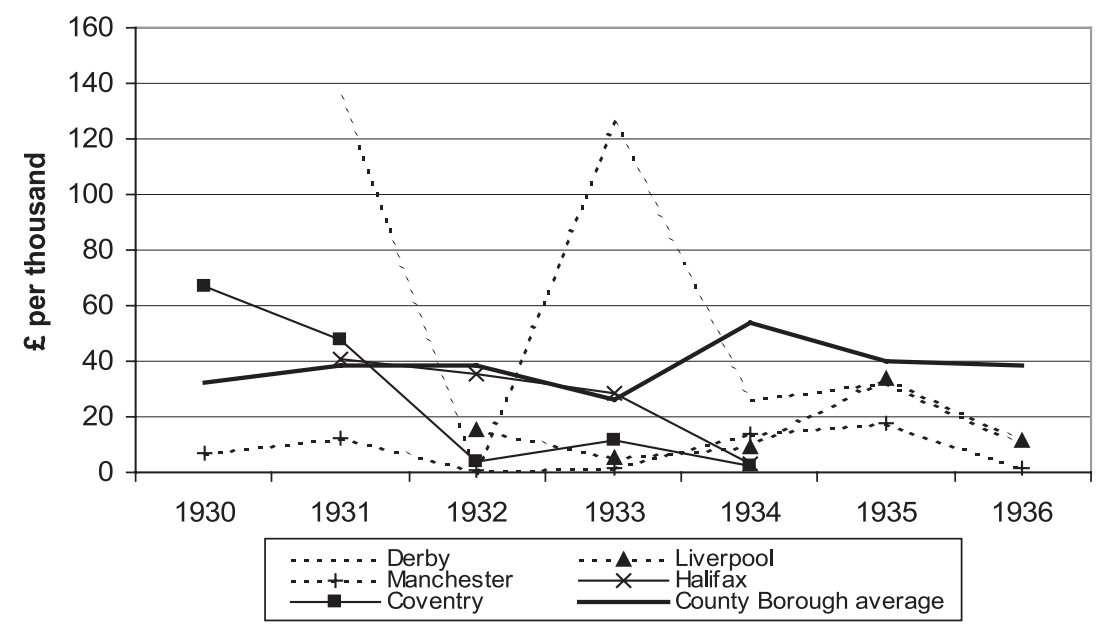

Figure 3: Capital investment on general hospitals in selected county boroughs, 1930-36.

Source: Local government financial statistics, 1930-36.

projects, of which there appear to have been two, in 1931 and 1933. This suggests a rapid commitment to development and improvement, although it may also indicate that the buildings inherited by Derby were in a very poor condition, necessitating heavy investment. Liverpool and Manchester also matched their revenue expenditure with capital outlay. Although not on the scale of Derby, Liverpool did spend at a higher level from the capital account in 1935, the same year that it showed a rise in revenue expenditure. It should be borne in mind, however, that Liverpool had several institutions while Derby did not, making the latter's capital outlay the more impressive. Manchester too spent at a raised level on capital projects in the last years of the period, as it did out of rate income, although the level was not very high. Generally, therefore, the boroughs which showed a rise in revenue expenditure showed a matching rise in capital projects. Those which spent at a steadier level, though, occasionally did still commit themselves to capital development. The expenditure data do, therefore, suggest a variation in the continued policy towards appropriated hospital buildings in different boroughs-from those which maintained a consistent level of spending, perhaps investing in capital, to those which were more energetic in their policy. Again, much probably depended both on the need for capital investment when the hospital was handed over from the PAC, and on council attitudes.

\section{Conclusions}

In this article we have provided a fuller and more dynamic picture of hospital appropriation than hitherto. We have been able to highlight both choices and constraints at work on a borough's ability and decision to appropriate hospitals. The former centre on the institutional provision inherited from the Poor Law, and the resources available to the borough. In most cases, lack of finance was not taken as an adequate reason not to 


\section{Alysa Levene, Martin Powell and John Stewart}

appropriate by the Ministry of Health, and the real constraints were the absence of a transferred institution, or one which was not suitable for acute hospital work. This focus on the nature of the inherited institutions largely reinforces conventional wisdom, but its extent has been quantified here for the first time. In terms of choices, much depended on the attitudes and preferences of the council, including the personalities of individual officers and personnel. Politics, at least in the sense of party affiliation, seems to have played a lesser role than local conflicts. The amount of hospital provision provided by the voluntary sector or by neighbouring boroughs also affected appropriation.

Statistical investigation of some of these variables indicated that population was the only significant factor explaining a borough's choice of whether to appropriate. Larger boroughs were much more likely to take this course than smaller ones. Small population size was a factor highlighted by Bevan as working against appropriation in some boroughs, and it appears on the basis of the statistical evidence that he was correct. The amount of voluntary provision played a smaller role in determining appropriation. The latter was, however, only the start of the development of hospital policies, and the course of subsequent investment differed considerably in different boroughs. Some maintained a constant level, either spending at a high or a low level, while others made substantial cash injections into their hospitals. The latter group frequently invested also in capital projects, which may have contributed to the rises in revenue expenditure. Even the low spenders may have made capital improvements, or replaced old buildings.

By 1936, therefore, thirty-seven boroughs had appropriated at least one general hospital, and many had continued to invest and make improvements. The standards achieved by this new and expanding sector are debated. Powell has noted the argument that increasing usage and demands on the municipal hospitals made them approach the level of the acute voluntary hospitals. ${ }^{98}$ In other cases, however, the poor standard of some appropriated institutions made the development of modern surgery, medicine, and nursing unlikely, at least in the short term. As George Godber stated, "it does matter much more what you do in buildings than what their physical resources are". 99 The judgement of standards is further complicated by the possibility of overcrowding and poor practices, and even by more nebulous, though undoubtedly valid concepts, such as the "hospital consciousness" of the populace, that is its propensity to use hospital services. The perceptions of hospitals as a sign of civic pride, or as a bastion of civic élites are also difficult to quantify. ${ }^{100}$ Countrywide, hospital standards varied considerably, reflecting the importance attached to local autonomy, but echoing the contemporary criticisms that the 1929 act perpetuated uneven and inequitable standards. It is clear from the foregoing analysis that both choices and constraints played a large part in this uneven development, and that some boroughs did not do as much as they could have done. Boroughs with sufficient population, however, coupled with energetic personnel and a suitable institution, took significant steps towards the development of a first class hospital service; a development made no less significant by the widespread changes of the 1940s.

${ }^{98}$ Ibid., pp. $344-5$.

${ }^{99}$ Godber, op. cit, note 2 above, p. 8.

${ }^{100}$ According to Marguerite Dupree, both the character of the local élite, and the legacy of charitable institutions from an earlier age had a large impact on local social services; see idem, 'The provision of social services', in Martin Daunton (ed.), The Cambridge urban history of Britain, vol. 3: 1840-1950, Cambridge University Press, 2000, pp. 351-94, on p. 355. 
Municipal Hospital Care in English County Boroughs

Appendix

County Borough General Hospital Accommodation and Appropriation Dates

\begin{tabular}{|c|c|c|c|}
\hline County Borough & Institution & Beds in 1929 & Date of Appropriation \\
\hline Barnsley & $\begin{array}{l}\text { Gawber Road PAI and } \\
\text { Hospital }\end{array}$ & 254 & 1937 \\
\hline Barrow-in-Furness & Roose mixed PAI & & \\
\hline Bath & Frome Road House PAI & 220 & \\
\hline Birkenhead & Tranmere Infirmary & 596 & $01 / 04 / 33$ \\
\hline \multirow[t]{2}{*}{ Birmingham } & Dudley Road Hospital & 926 & $01 / 04 / 30$ \\
\hline & $\begin{array}{l}\text { Selly Oak Hospital and } \\
\text { Infirmary }\end{array}$ & 450 (hospital) & $\begin{array}{l}\text { hospital 01/04/1930, } \\
\quad \text { institution 01/01/1933 }\end{array}$ \\
\hline Blackburn & Queen's Park Hospital & 499 & $01 / 04 / 39$ \\
\hline Blackpool & None & & \\
\hline Bolton & $\begin{array}{l}\text { Townley's hospital } \\
\text { Fishpool PAI }\end{array}$ & 520 & $01 / 04 / 39$ \\
\hline Bootle & None & & \\
\hline Bournemouth & Fairmile House mixed PAI & & \\
\hline Bradford & St Luke's Hospital & 863 & 1930 \\
\hline Brighton & Elm Grove PAI & 449 & $01 / 11 / 35$ \\
\hline Bristol & $\begin{array}{l}\text { Southmead Hospital } \\
\text { Eastville PAI }\end{array}$ & 566 & $01 / 04 / 30$ \\
\hline Burnley & Primrose Bank PAI & 281 & $01 / 04 / 33$ \\
\hline Burton-upon-Trent & Belvedere Road PAI & & \\
\hline Bury & None & & \\
\hline Canterbury & Nunnery Fields PAI & & \\
\hline Carlisle & Fusehill PAI & 140 & $01 / 06 / 37$ \\
\hline Chester & City Hospital & & $01 / 01 / 37$ \\
\hline Coventry & $\begin{array}{l}\text { London Road Infirmary (later } \\
\text { Gulson Road Hospital) } \\
\text { Exhall PAI }\end{array}$ & 388 & $01 / 04 / 30$ \\
\hline Croydon & Mayday Hospital & 460 & $01 / 04 / 32$ \\
\hline Darlington & Feetham PAI & & \\
\hline Derby & City Hospital and workhouse & 253 & 1931 \\
\hline Dewsbury & None & & \\
\hline Doncaster & Springwell House PAI & & \\
\hline Dudley & None & & \\
\hline East Ham & None & & \\
\hline Eastbourne & St Mary's mixed PAI & 140 & \\
\hline Exeter & Heavitree Road mixed PAI & & \\
\hline Gateshead & $\begin{array}{l}\text { High Teams PAI (later } \\
\text { Bensham Hospital) }\end{array}$ & 400 & \\
\hline Gloucester & City General Hospital & & 1936 \\
\hline Grimsby & Scartho Road PAI & & 1937 \\
\hline Gt Yarmouth & City PAI & & \\
\hline Halifax & $\begin{array}{l}\text { Gibbet Street Poor Law } \\
\text { Institution }\end{array}$ & & \\
\hline
\end{tabular}


Alysa Levene, Martin Powell and John Stewart

\begin{tabular}{|c|c|c|c|}
\hline County Borough & Institution & Beds in 1929 & Date of Appropriation \\
\hline Halifax & St Luke's Poor Law Hospital & 400 & $01 / 04 / 31$ \\
\hline Hastings & $\begin{array}{l}\text { City Poor Law Institution and } \\
\text { Municipal Hospital }\end{array}$ & 530 & \\
\hline Huddersfield & $\begin{array}{l}\text { Crosland Moor PAI (later } \\
\text { St Luke's) } \\
\text { Deanhouse Institution (later } \\
\text { St Mary's) }\end{array}$ & 213 & \\
\hline Ipswich & $\begin{array}{l}\text { Heathfields Municipal } \\
\text { Hospital and PAI }\end{array}$ & & $01 / 04 / 38$ \\
\hline Kingston-upon-Hull & $\begin{array}{l}\text { Anlaby Road PAI } \\
\text { Beverley Road PAI }\end{array}$ & 519 & \\
\hline Leeds & $\begin{array}{l}\text { St James' Hospital } \\
\text { St Mary's Hospital } \\
\text { Rothwell PAI } \\
\text { Holbeck PAI } \\
\text { Beckett St PAI }\end{array}$ & $\begin{array}{r}1398 \\
270\end{array}$ & $\begin{array}{l}01 / 10 / 34 \\
01 / 10 / 34 \\
01 / 10 / 34\end{array}$ \\
\hline Leicester & $\begin{array}{l}\text { Swain Street PAI } \\
\text { North Evington Infirmary } \\
\quad \text { (later City General hospital) }\end{array}$ & 550 & $01 / 04 / 30$ \\
\hline Lincoln & Burton Road PAI & 158 & \\
\hline Liverpool & $\begin{array}{l}\text { Alder Hey Hospital } \\
\text { Mill Road Hospital } \\
\text { Belmont Road PAI }\end{array}$ & $\begin{array}{l}900 \\
750\end{array}$ & $\begin{array}{l}1932 \\
1931\end{array}$ \\
\hline & $\begin{array}{l}\text { Walton Road mixed PAI } \\
\text { Smithdown Road mixed PAI }\end{array}$ & $\begin{array}{r}1661 \\
800\end{array}$ & $\begin{array}{l}01 / 04 / 35 \\
29 / 03 / 38\end{array}$ \\
\hline Manchester & $\begin{array}{l}\text { Crumpsall Hospital } \\
\text { Withington Hospital } \\
\text { Booth Hall Hospital } \\
\text { Withington PAI }\end{array}$ & $\begin{array}{r}1444 \\
1368 \\
750\end{array}$ & $\begin{array}{l}1930 \\
1930 \\
1930\end{array}$ \\
\hline Middlesborough & $\begin{array}{l}\text { Holgate PAI } \\
\text { Holgate Hospital }\end{array}$ & 272 & 1930 \\
\hline $\begin{array}{l}\text { Newcastle-upon-Tyne } \\
\text { Northampton }\end{array}$ & $\begin{array}{l}\text { Newcastle General Hospital } \\
\text { PAI and Infirmary }\end{array}$ & & 1930 \\
\hline Norwich & PAI and Infirmary & 273 & \\
\hline Nottingham & $\begin{array}{l}\text { Bagthorpe Infirmary (later } \\
\text { City Hospital) }\end{array}$ & 767 & $01 / 04 / 35$ \\
\hline $\begin{array}{l}\text { Oldham } \\
\text { Oxford }\end{array}$ & $\begin{array}{l}\text { Boundary Park PAI } \\
\text { Cowley Road PAI } \\
\text { London Road PAI }\end{array}$ & 420 & April 1930 \\
\hline Plymouth & $\begin{array}{l}\text { Greenbank House PAI (later } \\
\text { City Hospital) } \\
\text { Ford House PAI } \\
\text { Stonehouse PAI }\end{array}$ & 300 & $01 / 04 / 30$ \\
\hline
\end{tabular}


Municipal Hospital Care in English County Boroughs

\begin{tabular}{|c|c|c|c|}
\hline County Borough & Institution & Beds in 1929 & Date of Appropriation \\
\hline Portsmouth & St Mary's Infirmary* & 1200 & $\begin{array}{l}\text { Payments made under general } \\
\text { hospitals from } 1933 / 4\end{array}$ \\
\hline Preston & Fulwood Union Hospital* & 213 & $\begin{array}{l}\text { Payments made under general } \\
\text { hospitals by } 1932 / 3\end{array}$ \\
\hline Reading & Battle Infirmary* & 608 & $\begin{array}{l}\text { Payments made under general } \\
\text { hospitals by } 1930 / 1\end{array}$ \\
\hline Rochdale & Birch Hill Hospital & 659 & $01 / 04 / 30$ \\
\hline Rotherham & Alma Road PAI & 124 & $01 / 04 / 38$ \\
\hline Salford & Hope Hospital & & $\begin{array}{l}\text { Payments made under general } \\
\text { hospitals from } 1935 / 6\end{array}$ \\
\hline \multirow[t]{2}{*}{ Sheffield } & Union Hospital* & 834 & $\begin{array}{l}\text { Payments made under general } \\
\text { hospitals by } 1930 / 1\end{array}$ \\
\hline & Nether Edge Hospital & 500 & $\begin{array}{l}\text { Payments made under general } \\
\text { hospitals by } 1930 / 1\end{array}$ \\
\hline Smethwick & 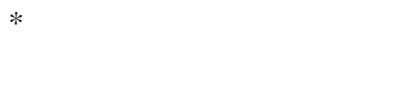 & & $\begin{array}{l}\text { Payments made under general } \\
\text { hospitals by } 1934 / 5\end{array}$ \\
\hline South Shields & $\begin{array}{l}\text { Harton PAI (later the General } \\
\text { Hospital) }\end{array}$ & & $1936 / 7$ \\
\hline Southampton & Borough Hospital & 542 & 1930 \\
\hline Southend-on-Sea & $*$ & & $\begin{array}{l}\text { Payments made under general } \\
\text { hospitals by } 1930 / 1\end{array}$ \\
\hline Southport & $*$ & & 1931 \\
\hline St Helens & None & & \\
\hline \multirow[t]{2}{*}{ Stockport } & Shaw Heath PAI & & \\
\hline & Stepping Hill Hospital & 450 & $01 / 04 / 38$ \\
\hline \multirow[t]{2}{*}{ Stoke-on-Trent } & London Road PAI & 600 & \\
\hline & Turnhurst Road PAI & 260 & \\
\hline Sunderland & Highfield PAI & 389 & $01 / 04 / 31$ \\
\hline Tynemouth & $*$ & & \\
\hline Wakefield & * & & \\
\hline Wallasey & None & & \\
\hline Walsall & $\begin{array}{l}\text { Beacon Lodge PAI and Manor } \\
\text { Hospital }\end{array}$ & 193 & $01 / 04 / 36$ \\
\hline Warrington & $\begin{array}{l}\text { Whitecross PAI (hospital } \\
\text { renamed Borough General } \\
\text { Hospital) }\end{array}$ & 300 & $01 / 04 / 30$ \\
\hline West Bromwich & $\begin{array}{l}\text { Hallam House PAI and } \\
\text { Hospital }\end{array}$ & 400 & $01 / 04 / 30$ \\
\hline \multirow[t]{3}{*}{ West Ham } & Whipps Cross Hospital & & \\
\hline & $\begin{array}{l}\text { Forest Gate Sick Home and } \\
\text { PAI }\end{array}$ & & \\
\hline & The Central Home PAI & & \\
\hline West Hartlepool & $\begin{array}{l}\text { Howbeck Institution and } \\
\text { Hospital }\end{array}$ & & \\
\hline
\end{tabular}


Alysa Levene, Martin Powell and John Stewart

\begin{tabular}{llll}
\hline County Borough & Institution & Beds in 1929 & Date of Appropriation \\
\hline Wigan & Frog Lane PAI & \\
& Billinge Infirmary & \\
Wolverhampton & New Cross Infirmary* & 390 \\
Worcester & Shrub Hill Infirmary* & 143 \\
York & York PAI* & 381 \\
\hline
\end{tabular}

* Survey not extant at NA.

Sources: Ministry of Health county borough survey reports, correspondence and re-surveys, National Archives (NA), MH66; Ministry of Health/Nuffield Provincial Hospitals Trust, The hospital surveys, London, 1945-6; Local government financial statistics, 1930-36; Burdett's Hospitals and Charities Yearbook, 1929, London, Faber and Gwyer, 1929. 